\title{
EVALUATING SENSITIVITY OF MACROECONOMIC FACTORS TO STOCK RETURN USING ARBITRAGE PRICING THEORY FRAMEWORK: EVIDENCE FROM INDONESIA STOCK MARKET
}

\author{
Jonathan Evan ${ }^{\mathrm{a}}$, Yanuar Dananjaya ${ }^{\mathrm{b}}$, Bertha Silvia Sutejo $^{\mathrm{c}}$ \\ ajonathanevan703@gmail.com \\ ${ }^{a}$ The Student of Master Program in Management at Pelita Harapan University, Surabaya 60234, Indonesia \\ ${ }^{b, c}$ The Lecturer of Master Program in Management at Pelita Harapan University, Surabaya 60234, Indonesia
}

\begin{abstract}
An investor needs to understand the factors that drive the return of shares in the stock market. The movement of share price caused by many factors and investors revaluated the price based on their own asset valuation method. One of the Asset valuation methods is the Arbitrage Pricing Theory (APT). The APT method is used to test several factors that are systematic. Systematic factors refer to the factors that can not be diversified and giving an impact to the entire sectors on the stock market. This study examines risk factors from macroeconomics that are systematic towards stock return movements. The sample used is stocks that have good capitalization, liquidity, and liquidity so that they can become members of the Kompas100 index in Indonesian Stock Exchange (IDX). This study measures the systematic risk of each economic factor such as inflation, interest rates, GDP rates, and changes in exchange rates for stocks listed on the Kompas 100 index with a sample period of 2015 to 2019. The method for data analysis using double regression, which are time-series regression and cross-section regression.

The results showed that the risk of inflation and the risk of the GDP rate had a positive but insignificant impact, while the risk of interest rates and the risk of changes in value had a significant negative impact on the value of stock returns and APT can explain $32 \%$ of the causes of stock price movement
\end{abstract}

Keywords: Arbitrage Pricing Theory Model; Macroeconomic Risk; Systematic Risk; IDX

\section{Introduction}

Investment becomes more popular in this age because of big improvements in the investing method. These days, an investment can be done using a mobile phone which means everywhere and every time. One of the investment options that become popular is investing in the stock market. Stock market offering higher return rather than other investment option, but surely also a higher risk that needs to be born by the investors. In a need to understand the risk of the stock market, the investors need to understand some factors which drive the stock price. One of the factors that drive the price changes in the stock valuation from investors because investors believe in the law of one price.

This paper updates the result of the arbitrage pricing theory model in the Indonesian stock market. Variables used in the research are the inflation rate, interest rate, GDP growth, and exchange rate because they have systematic risk. This paper also found a research gap between the concept "High Risk, High Return" in the research of Chen, Roll, \& Ross (1986) which show all risks have a positive significant impact on stock return. There is some research did a stock valuation using the arbitrage pricing theory model framework and found that some variables have a negative correlation on stock return, this result is contrary to the research of Chen, Roll, $\&$ Ross (1986). The previous research that found a negative correlation will be explained in the next chapter. It is important to explore why this gap happens and updating the research about arbitrage pricing theory to see its relevance to stock return movement. 
This paper aims to explain how a macroeconomic risk can impact the stock return movement. The result will show us how big and either significant or not a macroeconomic risk affects stock return movement. The result is also expected to be used as proof of the concept "High Risk, High Return" in the Indonesian stock market. Research by Dwipayana \& Wiksuana (2017) declared that the Indonesian stock market is a semi-strong form in the efficient market hypothesis. It will be quite interesting because in a semi-strong form market usually, stock return movement does not reflect the information announced by the country or corporate itself. In the chapter two explain about the ground theory and related previous research used in this paper. In the chapter three explain about all data including sample, population, operational variabel and analysis method. in the chapter four explain about the result and disccusion to the problem

\section{Literature Review}

\subsection{Asset Valuation}

The capital asset pricing model (CAPM) was first proposed by William Sharpe in 1964. The purpose of CAPM is to examine how systematic risk affects expected stock returns. CAPM states that investors must accept the expected return on defensive security. Defensive security means securities that have minimal risk as measured by the change in the value of the expected return resulting from a change in risk. On the other hand, if investors expect a higher expected retrun value, they can invest in aggressive security. Aggressive security apdat is defined as securities that have a sufficient level of risk high, namely the change in the value of a large stock return when a risk changes (Sharpe, 1964). This model has been tested and approved in research by John Lintner and Jan Mossin who tested CAPM (Lintner, 1965) (Mossin, 1966).

CAPM is not a perfect model in calculating expected return because it has drawn criticism from research by Richard Roll. Roll found that CAPM can only be implemented only by fulfilling the assumptions and conditions of the predetermined model. Some of these assumptions and conditions are almost impossible to fulfill. One of the assumptions that hinder CAPM is the assumption that investors regarding the exact composition of the portfolio composition to be used as a test on the model. This assumption can be interpreted that in testing the model all assets must be included to meet the requirements of CAPM. The assets that should be taken into account are the value of shares, the value of gold, world oil to collectibles, and at CAPM all these assets must be tested simultaneously so that it becomes impossible to fulfill the assumptions required by CAPM.

The many assumptions and several other weaknesses of CAPM lead to the need for the development of other models to calculate expected stock returns. The next model is expected to be more accurate and with less assumptions than the CAPM. One of the models developed to be proposed as a replacement for CAPM is arbitrage pricing theory (APT).

Arbitrage piricing theory is a theory proposed by Ross in 1976. The model that was developed by the APT has the same function as CAPM, which is to calculate expected return by testing systematic risk against historical stock returns. In this theory, the use of systematic risk is based on the consideration that the risk will affect changes in the overall stock return. Systematic risk is the risk that cannot be eliminated using any diversification method.

The factor that is taken into account in the APT model is unlike the CAPM which is only based on my one factor, namely market risk. In testing using the APT model, more than one factor may be used provided that the type of risk of these factors must be systematic. By considering several factors as sources of changes in the 
value of stock returns, it is hoped that it can explain which factors have a significant ability to change the value of stock returns. One of the systematic factors is macroeconomic and based on research by Chen, Roll, \& Ross (1986) it is concluded that macroeconomic factors have a significant impact on stock returns.

Roll and Ross once conducted an investigation using the APT model in calculating the expected return. Based on the APT concept, testing is carried out through two stages of regression. The first regression to find the beta value, and the second regression to find the gamma value. Beta is a value that shows the sensitivity of the stock return which is influenced by changes in the value of a factor. Gamma is a value that shows the sensitivity of the stock return value to changes in the sensitivity value or beta of a factor (Roll \& Ross, 1980).

One of the conditions for the effectiveness of this model is the efficient market hypothesis. The more efficient the form of the capital market, the more valid the APT model will be. In the case raised, namely the Indonesian capital market, the level of efficiency of the capital market is in a half-strong form (Dwipayana \& Wiksuana, 2017). So that the capital market in Indonesia meets the requirements for using the APT model.

\subsection{Previous Research}

Research by Amtiran, Indiastuti, Sulaeman, and Masyita (2017) is a reference in shaping the research model and the variables used in this study. The purpose of their research is to see the impact between the risk of macroeconomic variables and the value of stock returns with the APT framework. This study uses secondary data taken from the Indonesian capital market directory (ICMD) and the central statistical agency from 2007 to 2014. The sample used in their research is 80 manufacturing companies listed on the IDX. The analytical method used is Ordinary Least Square (OLS).

In his research, the macroeconomic variables used are the inflation rate, interest rate, GDP, exchange rate, and industrial production index. From each of these variables, the risk value (beta) is sought. The hypothesis of these researchers is that all risks from these macroeconomic factors have a positive impact on the value of stock returns. The hypothesis in this study is based on research by Chen, Roll, \& Ross (1986). Chen, Roll, \& Ross (1986) Neither is a theory that would argue that the relationship between financial markets and macroeconomic factors is entirely in the same direction. However, the stock price usually depends on external factors. Even though macroeconomics is considered an external factor, these factors can still be classified as endogenous variables, namely variables that have an impact on other variables in one model. Only natural disasters such as supernovae, earthquakes and so on can be classified as exogenous variables in the world economy Chen, Roll, \& Ross (1986).

Referring to research from Chen, Roll, \& Ross (1986), Amtiran has an assumption that the level of inflation risk has a positive impact on the rate of return of an issuer. According to Chen, Roll, \& Ross (1986) Changes in the rate of inflation will affect the nominal cash flow and of course in line with the value of the interest rate. To the extent that pricing is carried out in real terms, unanticipated changes in the price level will have a systematic effect, and to the extent that relative prices change with the general inflation rate, there will be changes in asset valuation related to changes in the average inflation rate. Moreover, the risk value, the higher the risk value will cause an increase in the expected profit required by investors.

However, the results of research from Amtiran, Indiastuti, Sulaeman, and Masyita (2017) do not support the theory of Chen, Roll, \& Ross (1986) because they conclude that the risk of inflation has a negative impact even though it is not statistically significant. There is no satisfactory explanation that explains these results, but it is 
suspected that it was due to using extreme data in 2008 which caused differences between the results and the hypotheses written at the beginning of the study. It does not need to be questioned that the return value is predicted to increase theoretically when the risk value increases.

Although these three factors have a correlation in line with the hypothesis, the research results show that the risk of the GDP rate has a low level of significance, so it cannot be said that the risk of this GDP rate affects the value of stock returns significantly. In this study, there is no satisfactory explanation regarding the insignificance of the impact of inflation risk and GDP risk on the value of stock returns.

A research by uses five macroeconomic factors as the cause of the theoretical stock return impact. These factors include risk premium, industrial production, term structure, and inflation. The data used is monthly data for four years, namely April 2012 to February 2016 in six developed and developing countries. The countries that were the objects of research were Singapore, Thailand, Malaysia, the Philippines, Malaysia, and Indonesia.

In this study, the findings indicate that inflation is an insignificant factor in predicting the domestic market. The research model used is APT because it is closely related to macroeconomic factors. The APT robust test is also tested for its effectiveness compared to CAPM. The results of the robust test show that the APT is worse than the CAPM, and the APT is not suitable for use in the capital market in Indonesia and Malaysia.

Research by Winarto, Sule, \& Ariawati (2016) replicates the research of Chen et. al. (1986) on the grounds that their research is research that uses macroeconomics for the first time. This study collaborates the method used by Chen et. al. (1986) with research Elton, Gruber, May (1994) who replicated and found that macroeconomics has a share in stock price changes.

This study uses quarterly data from March 2009 to December 2013. The object of this research is stocks that have good liquidity on the Indonesian stock exchange. The data used were obtained from ICMD and the official website of Bank Indonesia. This study uses the APT frame of mind as a research model in accordance with the research it refers to. The independent variables used are the risk of long-term SUN interest rates, inflation, and exchange rates according to research by Chen et. al. (1986), and the price of gold according to research by Elton, Gruber, May (1994).

In this study, the data used refers to the LQ45 index. The method of selecting the stock list in this study is given a condition, which must be consistently listed on the LQ45 index. The use of indexes is based on the liquidity requirements of a share to reflect changes in the risk value of a macroeconomic factor. LQ45 is 45 stocks that are considered to have the best liquidity level than other stocks listed on the Indonesian stock exchange. Of the 45 listed stocks, only 25 were selected that are consistently on the index.

This research uses risk factors for long-term government bonds, inflation rate, exchange rate, and gold price. In this study, there are four hypotheses for each factor which are all thought to have a negative impact or correlation on stock prices, in contrast to research by Chen et. al. (1986). The presumption refers to previous studies having hypotheses and the results, namely the negative impact of a factor's risk on stock returns.

in the research by Paavola 2006 believed that stock prices reacted to economic news. In this study, trying to do asset pricing using the APT model as a new model with several factors because CAPM is very commonly used. The purpose of this research is what factors influence the Russian capital market and how well the APT model can be used in that capital market. 
In this study, the sample was selected using the criteria of the largest company and obtained as many as 20 companies. The data taken is historical data from these 20 stocks from 1999 to 2006 . As for the criteria for selecting independent variables, it does not have a specific reference for both identity and number, so this study uses logic of thinking, namely factors that are not only systematic risk, but also is unique to the country. Broadly speaking, this means that common factors are discussed and become benchmarks for shifting economic conditions.

The selected factors are inflation, money supply, oil price, exchange rate, MSCI, and industrial production. Based on the previously mentioned criteria, it can be said that these factors are the benchmarks of the Russian economic community in assessing an economic condition. Furthermore, these factors will undergo a two-step regression according to the research model from APT to describe the risk impact of each factor on stock returns.

The results of this study indicate that five of the six risk factors have a positive impact. Of course, these results support the research of Chen et. al. (1986) which is none other than one of the studies used as a reference in trying the APT model. The level of depiction of the model assessed using an R-square value of 0.916 was also considered very good, like research by Chen et. al. (1986). Unfortunately, there is no further explanation regarding the negative impact of exchange rate risk on the value of stock returns.

\subsection{Hypotesis Development}

In developing the hypothesis, this study uses previous studies as a reference. If a research gap occurs, namely the difference in results between two studies with similar methods, the researcher will use subjective decisions to determine which research will be referred to as the basis for developing the hypothesis.

The hypothesis that is formed is about the relationship between the risk of a macroeconomic variable and the stock return. This hypothesis refers to previous studies and considers the research gap that occurred between previous research studies. The choice of correlation will be based on using previous research which has stronger reasons as the basis for determining the hypothesis. In previous studies, there is a gap in research results in testing macroeconomic risk as an independent variable.

On the positive side using the concept of high-risk high return based on the journal from Fama (1970) which was then tested by Chen, Roll, \& Ross (1986) using macroeconomic variables. Based on this concept, the higher the risk value, the higher the expected value of the return. The direction of the movement between the risk value and the expected value gives a conclusion that the value of risk and return has a negative correlation.

In other studies, testing the risk impact value with the stock return value does not always result in a positive correlation. The impact of inflation, interest rate and exchange rate risks are negative in research by Winarto, Sule, \& Ariawati (2016). And in research from Amtiran, Indiastuti, Sulaeman, and Masyita (2017) found that one of the four factors tested, namely the risk of inflation has a negative impact on stock returns. All these supporting journals do not have strong reasons to explain the positive correlation between risk and return.

Apart from the direction of correlation, the level of significance is also very important. Given the results of research from French (2017) which states that the APT model is not feasible to be applied in Indonesia. Many previous studies on APT indicated that the APT model was quite feasible as an asset pricing tool in Indonesia using the model feasibility testing method. So that the hypothesis that is formed will read thus: 
H1: Inflation risk has a significant positive impact on the value of stock returns.

$\mathrm{H} 2$ : Interest rate risk has a significant positive impact on the value of stock returns.

H3: GDP rate risk has a significant positive impact on the value of stock returns.

$\mathrm{H} 4$ : The risk of changes in exchange rates has a significant positive impact on the value of stock returns.

2.4 Research Model

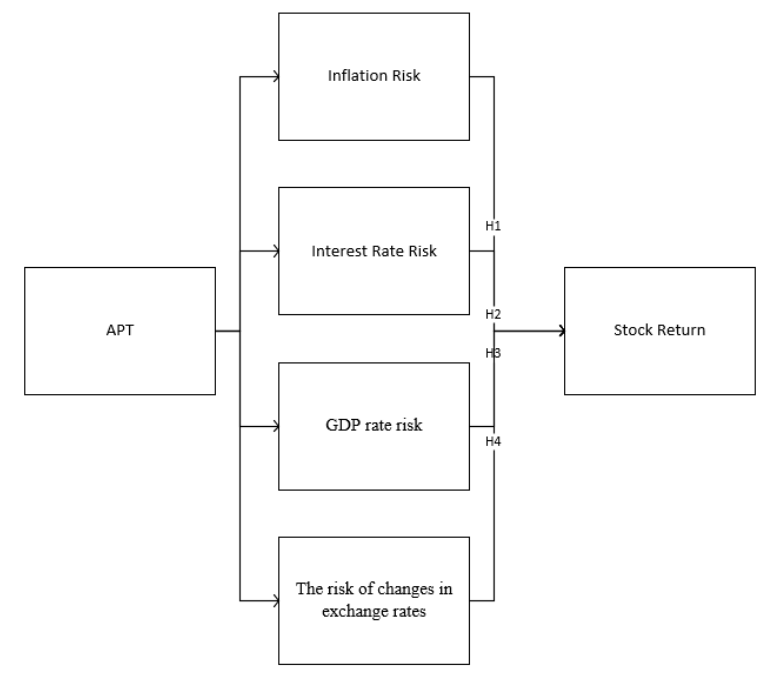

Figure 1: The Framework of Research* (Amtiran, Indiastuti, Sulaeman, \& Masyita, 2017)

*This framework refers to the second regression which evaluating macroeconomic risk against the stock return.

\section{Research Methods}

\subsection{Sample and Population}

This section describes the population of the study. The purpose of this section is to provide an overview of how big the actual population is compared to the sample used in data processing. The population of this study consists of all shares of companies listed on the Indonesian stock exchange until May 19, 2020. The selection of these dates is based on the initial time this research was started, and it is important to determine a point in time so that the population size does not change as the number of shares increases or decreases. companies listed on the Indonesian stock exchange. The number of shares listed on the Indonesian stock exchange at that time was 691 company shares. In the Indonesian stock exchange, there are nine main sectors as a reference for grouping. To illustrate how well the sample can represent the population, below will be provided a table containing a list of sectors listed on the Indonesian stock exchange and the number of companies belonging to the related sector.

This study uses an index reference to determine the number of companies and companies that will be tested. The choice of index compared to sectors is based on previous research which is a reference having the 
perspective that the use of companies that are incorporated in one sector will cause a high error because each sector has shares of companies with bad liquidity so that when tested with regression it will create an error.

The index is used to assist the process of screening company shares to match the criteria. In this research criterion, liquidity is important because good liquidity will cause stock prices to move every time there is a change in microeconomic, macroeconomic conditions, or other factors or information. In reference research, the LQ45 index was chosen because the specifications for screening and determining companies that are incorporated are based on liquidity criteria (Amtiran, Indiastuti, Sulaeman, \& Masyita, 2017). In this study, LQ45 is deemed insufficient to represent the population and will only produce a total of 45 beta to be tested in cross-section regression, so this study considers other indices that have good liquidity criteria and a larger number of listed company shares.

The Kompas100 index is an index in accordance with the needs of this study. The Kompas100 index has three main screening criteria, namely good fundamentals, good liquidity, and large capitalization. The Kompas100 index also has a list of company stocks that is more than the LQ45, which is as many as 100 company stocks so that it can produce as many as 100 beta to be tested in cross-section regression. The list of companies listed on the Kompas100 index will be updated every February and August, in this study the list of companies used is the Kompas100 index list in the February 2020 period. The data used in this study are monthly data with a time horizon of 2015 to 2019. The following is an overview companies on the Kompas 100 index along with a description of the number of companies that were sampled in each sector.

Table 1: Sample and population of the research

\begin{tabular}{|l|c|c|}
\hline \multicolumn{1}{|c|}{ Sector } & Sample & Population \\
\hline Agriculture & 3 & 22 \\
\hline Basic Industry dan Chemicals & 14 & 79 \\
\hline Consumer Goods Industry & 11 & 57 \\
\hline Finance & 12 & 93 \\
\hline Infrastructure, Utilities, dan Transportation & 9 & 78 \\
\hline Mining & 13 & 48 \\
\hline Miscellaneous Industry & 4 & 51 \\
\hline Property, Real Estate, dan Building Construction & 18 & 91 \\
\hline Trade, Services \& Investment Total & 16 & 172 \\
\hline \multicolumn{1}{|c|}{$\mathbf{1 0 0}$} & $\mathbf{6 9 1}$ \\
\hline
\end{tabular}

\subsection{Source of Data}

The data used in this study are secondary data. Secondary data refers to data sources that do not come from first-hand or original sources but from other parties who are specifically assigned to document historical data for public or commercial purposes. Secondary data collected in this study were obtained from reliable sources so that the data obtained were valid data. The following is a tabulation of data sources taken to be processed in this study: 
Table 2: Source of secondary Data

\begin{tabular}{|c|l|}
\hline Data & \multicolumn{1}{|c|}{ Source } \\
\hline Harga Saham & https://finance.yahoo.com/ \\
\hline Inflasi & https://www.bi.go.id/en/moneter/inflasi/data/Default.aspx \\
\hline Suku Bunga & https://www.bps.go.id/subject/13/keuangan.html\#subjekViewTab6 \\
\hline Produk Domestic Bruto & $\begin{array}{l}\text { https://www.bps.go.id/subject/11/produk-domestik-bruto--lapangan-usaha- } \\
\text {.html\#subjekViewTab6 }\end{array}$ \\
\hline Nilai tukar & https://www.bi.go.id/en/moneter/informasi-kurs/transaksi-bi/Default.aspx \\
\hline
\end{tabular}

\subsection{Operational Variable}

This section describes each variable used in testing, both independent and dependent variables. The purpose of this section is to provide an explanation of the definitions and formulas for measuring a variable. The definitions and measurements of each variable will be presented in the table below:

Table 3: The Operational Variable symbol and measurement

\begin{tabular}{|c|c|c|}
\hline Variable & Symbol & Measurement \\
\hline \multicolumn{3}{|c|}{ First regression (Time-series Regression) } \\
\hline Stock Return & $\mathrm{Xi}$ & $\frac{P_{t}-P_{t-1}}{P_{t-1}}+D$ \\
\hline Inflation Rate & $\delta_{\text {IFR }}$ & $\frac{\mathrm{IHK}_{\mathrm{t}}-\mathrm{IHK}_{\mathrm{t}-1}}{\mathrm{IHK}_{\mathrm{t}-1}}$ \\
\hline Interest Rate & $\delta_{\text {ITR }}$ & $\frac{\mathrm{ITR}_{\mathrm{t}}-\mathrm{ITR}_{\mathrm{t}-1}}{\mathrm{ITR}_{\mathrm{t}-1}}$ \\
\hline GDP rate & $\delta_{\mathrm{GDP}}$ & $\frac{\mathrm{GDP}_{\mathrm{t}}-\mathrm{GDP}_{\mathrm{t}-1}}{\mathrm{GDP}_{\mathrm{t}-1}}$ \\
\hline Changes in Exchange rate & $\delta_{\text {EXR }}$ & $\frac{\mathrm{EXR}_{\mathrm{t}}-\mathrm{EXR}_{\mathrm{t}-1}}{\mathrm{EXR}_{\mathrm{t}-1}}$ \\
\hline \multicolumn{3}{|c|}{ Second Regression (Cross-section Regression) } \\
\hline Average Stock Return & $\mathrm{E}_{\mathrm{i}}$ & $\frac{\Sigma X i}{\text { Total Data }}$ \\
\hline Inflation Rate Risk & $\beta_{\mathrm{i}, \mathrm{IFR}}$ & Result of time-series regression \\
\hline Interest Rate Risk & $\beta_{\mathrm{i}, \mathrm{ITR}}$ & Result of time-series regression \\
\hline GDP Rate Risk & $\beta_{\mathrm{i}, \mathrm{GDP}}$ & Result of time-series regression \\
\hline The risk of changes in exchange rates & $\beta_{\mathrm{i}, \mathrm{EXR}}$ & Result of time-series regression \\
\hline
\end{tabular}

\subsection{Data Analysis Method}

Multiple regression model is the main method in this research because it can produce sensitivity or sensitivity of each macroeconomic variable as an independent variable to the value of stock return as the dependent variable. In this study, there are two methods of multiple regression, namely time-series regression (1), and cross-section regression (2). 
Time-series regression is a regression method used to test the sensitivity of stock returns to a macroeconomic variable. The result of this regression is the beta value of each macroeconomic variable on each tested company stock. Time-series regression can be modeled as the following equation:

$\chi_{i}=E_{i}+\beta_{i, I F R} \delta_{I F R}+\beta_{i, I T R} \delta_{I T R}+\beta_{i, G D P} \delta_{G D P}+\beta_{i, E X R} \delta_{E X R}+\varepsilon_{1}$

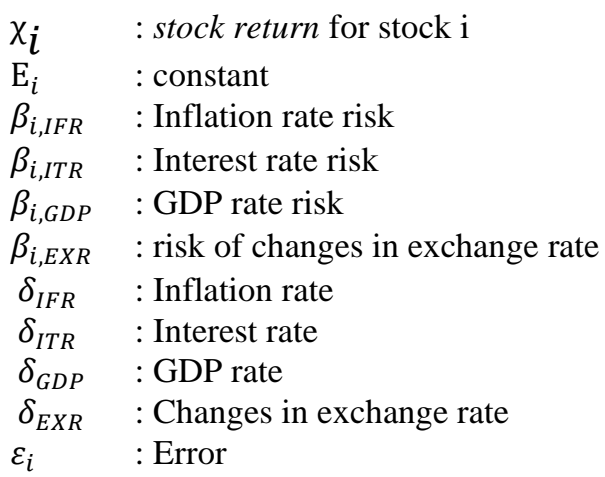

Cross-section regression is a regression method used to test the average stock return with each beta of a macroeconomic factor at one point in time or simultaneously. This method will produce the sensitivity of each beta from macroeconomic factors. Cross-section regression can be modeled in the following equation:

$$
E_{i}=\rho+\gamma_{I N F} \beta_{i, I F R}+\gamma_{I T R} \beta_{i, I T R}+\gamma_{G D P} \beta_{i, G D P}+\gamma_{E X R} \beta_{i, E X R}
$$

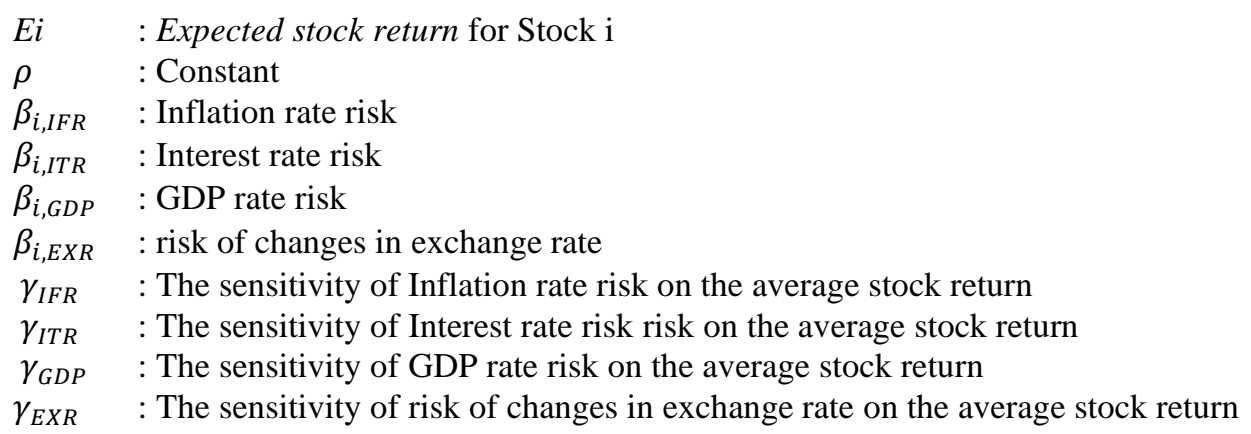

\section{Result and Discussion}

In this study, the sample used is a number of stocks listed on the Indonesian stock exchange from January 2015 to December 2019. The criteria for selecting a number of shares are based on the level of liquidity which can be seen from the transaction volume. In this study, it was decided to use the help of an index in determining the number of stocks that will be used as research samples, this index is the Kompas100 index.

Kompas 100 is an index containing 100 company stocks that are considered to have good levels of liquidity, fundamentals and capitalization. The use of the list on the Kompas100 index is based on data on stocks listed on the index in the first semester of 2020 when this research was conducted. After obtaining a list of 100 
company stocks that will be sampled, a further screening process is continued according to the needs of this study.

The screening process involves several additional criteria, such as the absence of a Suspend decision from the IDX on the 100 issuers of shares. This is very important to minimize the occurrence of errors due to cessation of stock price movements, when movements in macroeconomic conditions are unlikely to stop. The next criterion is regarding the minimum historical data requirements for each share. This study uses monthly historical data from the closing stock price from December 2015 to December 2019. So that the required data is as much as 61 data. Lack of data will cause a gap in equality when processing data. Data that does not meet the two additional requirements will be excluded. By applying these two conditions, the total data that meets the requirements is only 84, with details of 1 data being suspended and 15 data without historical data as much as 61 months back. By using Eviews, the data analysis and result will be provided below:

\begin{tabular}{|c|c|c|c|c|}
\hline \multicolumn{5}{|c|}{$\begin{array}{l}\text { Dependent Variable: AALI } \\
\text { Method: Least Squares } \\
\text { Date: 11/08/20 Time: } 21: 38 \\
\text { Sample: } 2015 \mathrm{M} 01 \text { 2019M12 } \\
\text { Included observations: } 60\end{array}$} \\
\hline Variable & Coefficient & Std. Error & t-Statistic & Prob. \\
\hline $\mathrm{C}$ & 1.210645 & 0.687193 & 1.761727 & 0.0837 \\
\hline INF & -1.586002 & 1.586640 & -0.999598 & 0.3219 \\
\hline ITR & -0.804375 & 1.470755 & -0.546913 & 0.5867 \\
\hline GDP & -21.87361 & 12.90670 & -1.694749 & 0.0958 \\
\hline EXR & 0.361968 & 0.656903 & 0.551022 & 0.5838 \\
\hline R-squared & 0.063437 & \multirow{7}{*}{\multicolumn{2}{|c|}{$\begin{array}{l}\text { Mean dependent var } \\
\text { S.D. dependent var } \\
\text { Akaike info criterion } \\
\text { Schwarz criterion } \\
\text { Hannan-Quinn criter. } \\
\text { Durbin-Watson stat }\end{array}$}} & -0.000863 \\
\hline Adjusted R-squared & -0.004676 & & & 0.096457 \\
\hline S.E. of regression & 0.096683 & & & -1.755111 \\
\hline Sum squared resid & 0.514114 & & & -1.580582 \\
\hline Log likelihood & 57.65332 & & & -1.686843 \\
\hline F-statistic & 0.931345 & & & 2.514906 \\
\hline Prob(F-statistic) & 0.452617 & & & \\
\hline
\end{tabular}

Figure 2: Time-series regression result for AALI

In the picture above, is the result of the first regression to get the beta value or what will be interpreted as the risk of each macroeconomic factor. In this figure it can be interpreted that the value of the inflation rate denoted as the "INF" variable, the interest rate denoted as the "ITR" variable, and the gross domestic product rate denoted as the "GDP" variable have a negative correlation, whereas only the change in value the exchange rate is denoted as "EXR" which has a positive correlation value with a value of 0.361968 and a constant value of 1.210646. So that if the result is notated in the form of an equation it will take the following form:

$$
\chi_{A A L I}=1.21604-1.586002 \delta_{I F R}-0.804375 \delta_{I T R}-21.87361 \delta_{G D P}+0.361968 \delta_{E X R}+\varepsilon_{1}
$$

The coefficient value of each of these macroeconomic factors then becomes the risk value of AALI's stock on inflation, interest rates, GDP rates, and changes in exchange rates. The process of finding the risk value is also carried out on 83 other stocks as the sample of this study and then the data is used as independent variable data in predicting its impact on the average stock return value. 
From the results above, it can be concluded that the movement of one point from the inflation rate will cause a stock price movement of 1.586002 points in the opposite direction. This means that an increase in the value of inflation by 1 point will have the potential to reduce the value of stock returns by 1.586002 points. Likewise, the movement in the value of interest rates and the rate of GDP which has the potential to produce the opposite impact from the direction of movement in value. Meanwhile, the interest rate seems to be the only positive factor, which can be interpreted that a one-point increase in the exchange rate will also cause an increase in the stock return value of 0.361968 points. The magnitude of the sensitivity of stock returns to macroeconomic value will then be called risk. The risk value of each economic factor and issuer will then become an independent variable which is thought to be endogenous so that it can explain changes in share prices.

In the cross-section regression stage, is the final stage in testing the data with the result that the sensitivity value of the beta of each issuer is tested simultaneously at one point in time. Following are the results of the cross-section regression:

\begin{tabular}{|c|c|c|c|c|}
\hline \multicolumn{5}{|c|}{$\begin{array}{l}\text { Dependent Variable: AVR } \\
\text { Method: Least Squares } \\
\text { Date: } 01 / 10 / 20 \text { Time: } 20: 44 \\
\text { Sample: } 184 \\
\text { Included observations: } 84\end{array}$} \\
\hline Variable & Coefficient & Std. Error & t-Statistic & Prob. \\
\hline C & 0.023809 & 0.003122 & 7.625938 & 0.0000 \\
\hline INF & 0.000228 & 0.000789 & 0.288323 & 0.7739 \\
\hline ITR & -0.003892 & 0.001055 & -3.687371 & 0.0004 \\
\hline GDP & 4.53E-09 & 8.96E-09 & 0.505516 & 0.6146 \\
\hline EXR & -0.005917 & 0.001759 & -3.364637 & 0.0012 \\
\hline R-squared & 0.324567 & \multicolumn{2}{|c|}{ Mean dependent var } & 0.015311 \\
\hline Adjusted R-squared & 0.290368 & \multicolumn{2}{|c|}{ S.D. dependent var } & 0.023720 \\
\hline S.E. of regression & 0.019982 & \multicolumn{2}{|c|}{ Akaike info criterion } & -4.930308 \\
\hline Sum squared resid & 0.031543 & \multicolumn{2}{|c|}{ Schwarz criterion } & -4.785616 \\
\hline Log likelihood & 212.0729 & \multirow{2}{*}{\multicolumn{2}{|c|}{$\begin{array}{l}\text { Hannan-Quinn criter. } \\
\text { Durbin-Watson stat }\end{array}$}} & -4.872143 \\
\hline F-statistic & 9.490512 & & & 2.119686 \\
\hline Prob(F-statistic) & 0.000003 & & & \\
\hline
\end{tabular}

Figure 3: The result of the Cross-section Regression

The picture above is the result of the regression of each beta value owned by the listed issuer as the sample. The risk value of inflation is denoted as the variable "INF", the value of interest rate risk denoted as the "ITR" variable, the risk value of the gross domestic product rate denoted as the "GDP" variable, and the risk value of changes in the exchange rate which is denoted as "EXR". The magnitude of the correlation value and the nature of the correlation can be seen in the coefficient column. These results indicate that of the four independent variables tested, two of them have a positive but insignificant correlation value, while the other two have a significant negative correlation. When illustrated by the equation it will be like the equation below:

$E_{i}=0.023809+0.000228 \beta_{i, I F R}-0.003892 \beta_{i, I T R}+0.0000000045 \beta_{i, G D P}-0.005917 \beta_{i, E X R}$

From this equation it can be interpreted that an increase in one point of risk from inflation will have an impact on the increase in expectations of global stock returns of 0.023809 points. In the equation above, the risk factors for inflation and the GDP rate will have the potential to move the stock return value in line with the movement 
of its value, while the risk of interest rates and exchange rates is negative, which means that it has the potential to move the stock return value in the opposite direction of its movement.

From the test results above, the probability value of the $t$ test on the risk factor for inflation and the GDP rate has a value of 0.7739 and 0.6146 respectively, which are greater than five percent, so it can be concluded that the risk of inflation and the GDP rate do not have a significant impact on the movement of values. stock return. Meanwhile, for the risk of interest rates in exchange rates, it has probability values of 0.0004 and 0.0012 which are below five percent, so it can be said that the risk of interest rates and exchange rates has a significant impact on stock return movements.

At this stage of the discussion, two important points will be discussed. first about the insignificance of a risk. It should be noted beforehand that the APT model has weaknesses, one of which is that there is no definite reference to the identity and number of factors that can be used as independent variables in explaining the fluctuation of the dependent variable (Tunah, 2013). The definite reference is that the identity of these factors must have the character of a systematic risk, and this has been considered by the authors and has been tested in the research of Chen, Roll, \& Ross (1986). So, the authors conclude that inflation risk and GDP rate risk are not factors considered by local and foreign investors who invest in the Indonesian capital market. The author's assumption regarding the insignificance of the impact of inflation risk refers to the movement of the inflation rate from year to year, which is increasingly stable. Of course, with the increased stability of inflation risk, this factor will no longer be the focus of attention of investors in investing in the Indonesian capital market.

With a negative correlation result, it will refute the concept of high-risk high return based on the journal from Fama (1970). This concept is the main concept in building each hypothesis in this study. The interpretation of these results is that the higher the risk, the lower the profit rate. Of course, this event deviates from the general way of thinking of investors. The deviation of a decision from an individual is based on the emotional turmoil that exists in everyone. This deviant behavior is closely related to the psychological influence of an investor's mind in receiving circulating information. So that according to research from Sahu, Padhy, \& Dhir (2020), it shows that behavioral finance is one of the intervening variables that can strengthen, weaken, or change the correlation direction of two variables. This supports research on the "balance theory" which states that there is a third variable as an intervening variable that can change the correlation direction of the behavior it should be (Heider, 1958)

One of the behavioral finances that can explain the deviation of the results of this study against the hypothesis is the concept of "lottery-like stocks". This concept explains the deviant behavior that investors have by targeting stocks whose movements are very fluctuating in the hope of getting a decent return on the risks they bear, which is indirectly the same as gambling (Gambling). Investors in the Indonesian stock exchange tend to transact in mid-cap stocks to small-cap stocks. The goal is to get a level of return that is proportional to the risks borne (Luxianto, Arief, \& Prasetyo, 2020).

From the explanation above, it can be concluded that the direction of the negative correlation of interest rate risk and risk of exchange rate changes may result from deviations in investor behavior. It should be noted that the sample in this study is big-cap stocks which have good fundamentals, liquidity, and market caps. With this behavior deviation, investors will get out of first-tier stocks because they must bear interest rate risk and exchange rate risk that have a systematic impact on all stocks, presumably because investors are not sure about stock price movements that will touch the expected return. So, they switch to second tier and third-tier stocks with the aim of getting a higher rate of return to pay for the risk borne. 
Previously, French (2017) stated that the APT model was not suitable for use in the Indonesian and Malaysian capital markets. In the results of this study, it was found that the model could be called feasible because it passed the $\mathrm{F}$ test, namely testing the feasibility of the model by testing the variables simultaneously. Apart from being feasible, the model is said to represent $32.4567 \%$ of anomalies that cause stock returns on the Indonesian stock exchange.

\section{Conclusion}

Stocks that have large capitalization and are considered as tier 1 stocks have a significant impact with a negative tendency. this is caused by the existence of behavioral finance that influences an investor's decision to make investment decisions. in the concept of "Lottery-like Stock" it is explained that there are some investors who tend to buy stocks that have a tendency like a lottery. This is intended so that investors can take an appropriate return according to the level of risk they must bear.

APT is also still suitable for use as an asset pricing tool in Indonesia because it can explain more than $30 \%$ of stock price anomalies on the Indonesian stock exchange.

for further research, we can consider second-tier stocks as samples to prove the author's conjecture. and do not use systematic variables that tend to fluctuate stable in a certain period.

\section{REFERENCE}

Amtiran, P., Indiastuti, R., Sulaeman, N., \& Masyita, D. (2017). Macroeconomic Factors And Stock Returns In APT Framework. International Journal of Economics and Management, 197-206.

Chen, N.-F., Roll, R., \& Ross, S. A. (1986). Economic Forces and the Stock Market. Chicago Journals, 383-403.

Dwipayana, I. G., \& Wiksuana, I. G. (2017). PENGUJIAN EFISIENSI PASAR DI BURSA EFEK INDONESIA. E-Jurnal Manajemen, 2105-2132.

Fama, E. (1970). Efficient Capital Markets: A Review of Theory and Empirical Work. Journal of Finance, $383-417$.

French, J. (2017). Macroeconomic Forces and Arbitrage Pricing Theory. Journal of Comparative Asian Development.

Heider, F. (1958). The psychology of interpersonal relations. John Wiley \& Sons Inc.

Lintner, J. (1965). The valuation of risk assets and the selection of risky investments in stock portfolios and capital budgets. Review of Economics and Statistics, 13-37.

Luxianto, R. A. (2020). Day-of-the-Week Effect and Investors' Psychological Mood Testing in a Highly Mispriced Capital Market. Journal of Indonesian Economy and Business, 257-269.

Mossin, J. (1966). Equilibrium in a Capital Asset Market. Econometrica, 768-783.

Paavola, M. (2006). TESTS OF THE ARBITRAGE PRICING THEORY USING MACROECONOMIC VARIABLES IN RUSSIAN EQUITY MARKET.

Roll, R. (1977). A CRITIQUE OF THE ASSET PRICING THEORY'S TESTS Part I: On Past and Potential Testability of the Theory* Journal of Financial Economics, 129-176.

Ross, S. A. (1976). The Arbitrage Theory of Capital Asset Pricing. Journal of Economic Theory, 341-360.

Ross, S. A. (1976). The Arbitrage Theory of Capital Asset Pricing. Journal of Economic Theory, 341-360.

Sahu, A. K. (2020). Envisioning the future of behavioral decision-making: A systematic literature review of behavioral reasoning theory. Australasian Marketing Journal (AMJ), 145-159.

Sharpe, W. F. (1964). Capital asset prices: A theory of market equilibrium under conditions of risk. Journal of Finance, $425-442$.

Winarto, J., Sule, E. T., \& Ariawati, R. R. (2016). Test of Arbitrage Pricing Theory: Evidence from Indonesia. International Journal of Management Sciences and Business Research, 2226-8235. 